\title{
Effects of medicinal plant ipe on expression of inducible nitric oxide synthase in inerleukin-1 $\beta$-stimulated Hepatocytes
}

\author{
Takashi Ozaki $^{1}$, Yusai Kawaguchi ${ }^{2}$, Kosuke Matsui ${ }^{1}$, Masaya Kotsuka ${ }^{1}$, Hiroya Iida ${ }^{3}$, \\ Masaki Kaibori ${ }^{1}$, Mikio Nishizawa ${ }^{4}$, Tadayoshi Okumura ${ }^{1 *, 5}$ and Mitsugu Sekimoto ${ }^{1}$
}

${ }^{1}$ Department of Surgery, Kansai Medical University, Hirakata, Osaka, 573-1191, Japan; ${ }^{2}$ Kitakawachifujii Hospital, Shijyonawate, Osaka, 573-1191, Japan; ${ }^{3}$ Department of Surgery, Shiga University of Medical Science, Kusatsu, Shiga, 525-8577, Japan; ${ }^{4}$ Department of Biomedical Sciences, College of Life Sciences Ritsumeikan University, Kusatsu, Shiga, 525-8577, Japan; ${ }^{5}$ Research Organization of Science and Technology, Ritsumeikan University, Kusatsu, Shiga, 5258577, Japan

*Correspondence: Tadayoshi Okumura, Ph.D, Department of Surgery, Kansai Medical University, 2-5-1 Shinmachi, Hirakata, Osaka, 573-1010, Japan

Submission Date: August 25 ${ }^{\text {th }}$, 2019. Acceptance Date: October 28 ${ }^{\text {th }}$, 2019; Publication Date: October $30^{\text {th }}, 2019$

Citation: Ozaki T, Kawaguchi Y, Matsui K, Kotsuka M, Iida H, Kaibori M, Nishizawa M, Okumura $\mathrm{T}$ and Sekimoto M. Effects of medicinal plant ipe on expression of inducible nitric oxide synthase in inerleukin-1 $\beta$-stimulated Hepatocytes. Functional Foods in Health and Disease 2019; 9(10): 648-661. DOI: https://doi.org/10.31989/ffhd.v9i10.650

\begin{abstract}
Background: The traditional medicine ipe is thought to have various pharmacological actions including anticancer and anti-inflammatory activities. However, there is little scientific evidence to demonstrate the organ-protective effects of ipe. The prevention of nitric oxide (NO) production in inflamed livers by inducible NO synthase (iNOS) is an indicator of liver protection. We examined proinflammatory cytokine-stimulated hepatocytes as a simple "in vitro liver injury model" to determine ipe's liver-protective effects of ipe and clarify its mechanisms. This study aims to examine whether ipe influences iNOS induction and NO production, and if so, the mechanisms involved in its action.
\end{abstract}

Methods: Primary cultured hepatocytes were treated with interleukin (IL)-1 $\beta$ in the presence or absence of ipe. The induction of iNOS and its signal pathway were analyzed.

Results: Ipe inhibited the production of NO stimulated by IL-1 $\beta$ and showed the greatest effect (more than $90 \%$ inhibition) at $2 \mathrm{mg} / \mathrm{ml}$. Ipe decreased iNOS protein and mRNA expression. Ipe decreased NF- $\kappa \mathrm{B}$ activation (its translocation to the nucleus and DNA binding), although there was no effect on I $\mathrm{B} \boldsymbol{\alpha} \alpha$ degradation. Ipe inhibited Akt activation, followed by decreased the type I IL-1 receptor mRNA and protein levels. Transfection experiments revealed that ipe decreased both activities of iNOS promoter transactivation and mRNA stability. In support of the latter 
observation, ipe inhibited the expression of the antisense transcript of the iNOS gene.

Conclusion: Ipe blocked IкB kinase and phosphatidylinositol 3-kinase/Akt signal pathways, which caused the reduction of iNOS mRNA synthesis and its stability. This resulted in the inhibition of iNOS induction and NO production. Ipe may have a potent beneficial effect against NO-mediated injury in organs including the liver.

Key words: ipe, inducible nitric oxide synthase, liver injury, primary cultured hepatocytes, nuclear factor- $\kappa \mathrm{B}$, the type I interleukin-1 receptor, iNOS antisense transcript

\section{INTRODUCTION}

Recent accumulated evidence indicates that traditional medicines, including domestic Kampo (Japanese herbal) and imported foreign medicines, and functional foods are clinically used to treat various diseases in Japan. Traditional medicines are used for pre- and post-operative treatments in patients with digestive diseases. Over $80 \%$ of physicians in Japan have some experience in using such medicines. One such medicine, ipe (ipe roxo, taheebo tea), is a traditional medicine extracted from the dried inner bark of Tabebuia avellanedae/ipe (lapacho tree), which is a popular tree distributed throughout the tropical rain forests of Central and South America. Ipe and its constituents, such as lapachol, are thought to have various pharmacological actions such as antiulcer, antibacterial, antioxidant, anti-inflammatory and anticancer activities [1-5].

In hepatic disorders, proinflammatory cytokines and nitric oxide (NO) produced by inducible nitric oxide synthase (iNOS) in Kupffer cells and hepatocytes play important roles as factors in liver injury [6], although NO exerts either detrimental or beneficial effects, depending on the insults and tissues involved. In animal liver injury models caused by various insults, such as ischemia-reperfusion, partial hepatectomy and endotoxin shock, we have previously reported that drugs showing liver-protective effects inhibited the induction of iNOS and NO production and decreased production of various inflammatory mediators, such as tumor necrosis factor (TNF)- $\alpha$, interleukin (IL)-1 $\beta$, IL-6 and cytokine-induced neutrophil chemoattractant (CINC)-1 (human IL-8 analogue) [7-11]. Furthermore, in in vitro experiments with primary cultured rat hepatocytes stimulated by IL-1 $\beta$, these drugs also inhibited iNOS induction and NO production $[9,12,13]$. Thus, by using our cultured hepatocytes, the prevention of iNOS induction and NO production is an indicator of liver protection. Recently Awale et al. reported that a water extract of the inner bark of taheebo from Brazil showed significantly inhibited NO production in lipopolysaccharideactivated J774.1 macrophage-like cells [14]. However, they did not find the mechanisms involved in the extract's action or its isolated constituents.

In the present study, we examined IL- $1 \beta$-stimulated cultured hepatocytes as a simple in vitro liver injury model.

\section{MATERIALS AND METHODS}

\section{Materials}

Ipe roxo powder (IkedaYakuso Co., Ltd., Osaka, Japan) and was dissolved in Williams' Medium $\mathrm{E}$ (WE), vortexed for $30 \mathrm{~min}$ at room temperature, followed by centrifugation $(9,000 \mathrm{rpm}(13,000$ 
$\times \mathrm{g}$ ) for $30 \mathrm{~min}$ at $4^{\circ} \mathrm{C}$, JA-12 rotor/Avanti HP-30I, Beckman Coulter Co., Ltd., USA). The supernatant (ipe extract) was filter-sterilized with a $0.45-\mu \mathrm{m}$ membrane filter (Millipore, Billerica, MA, USA) prior to use in experiments. Recombinant human IL-1 $\beta\left(2 \times 10^{7} \mathrm{U} / \mathrm{mg}\right.$ protein) was purchased from MyBioSource (San Diego, CA, USA). $\left[\gamma_{-}{ }^{32} \mathrm{P}\right]$ Adenosine-5'-triphosphate(ATP;222TBq/mmol)and $\left[\alpha_{-}{ }^{32} \mathrm{P}\right]$ deoxycytidine-5' -triphosphate (dCTP; $-111 \mathrm{TBq} / \mathrm{mmol}$ ) were obtained from DuPont-New England Nuclear Japan (Tokyo, Japan). Male Wistar rats (200-250 g, 6-7 weeks old) were purchased from Charles River (Tokyo, Japan), kept at $22^{\circ} \mathrm{C}$ under a $12: 12 \mathrm{~h}$ light:dark cycle, and given food and water ad libitum. All animal experiments were performed in accordance with the Guidelines for the Care and Use of Laboratory Animals of the National Institutes of Health and approved by the Animal Care Committee of Kansai Medical University.

\section{Primary hepatocyte cultures}

Hepatocytes were isolated from rats using collagenase (Wako Pure Chemicals, Osaka, Japan) perfusion $[15,16]$. Isolated hepatocytes were suspended in culture medium at $6 \times 10^{5}$ cells $/ \mathrm{ml}$, seeded into 35-mm plastic dishes ( $2 \mathrm{ml} /$ dish; Falcon Plastic, Oxnard, CA, USA) and cultured at $37^{\circ} \mathrm{C}$ in a $\mathrm{CO}_{2}$ incubator under a humidified atmosphere of $5 \% \mathrm{CO}_{2}$ in air. The culture medium was WE supplemented with 10\% newborn calf serum, Hepes $(5 \mathrm{mM})$, penicillin (100 units $/ \mathrm{ml})$, streptomycin $(0.1 \mathrm{mg} / \mathrm{ml})$, dexamethasone $(10 \mathrm{nM})$ and insulin $(10 \mathrm{nM})$. After $5 \mathrm{~h}$, the medium was replaced with fresh serum- and hormone-free WE, and the cells were cultured overnight before use in experiments. The numbers of cells attached to the dishes were calculated by counting the nuclei [17] and using a ratio of $1.37 \pm 0.04$ nuclei/cell (mean $\pm \mathrm{SE}, \mathrm{n}=7$ experiments).

\section{Cell treatment with ipe extract}

On day 1, the cells were washed with fresh serum- and hormone-free WE and incubated with IL$1 \beta(1 \mathrm{nM})$ in the same medium in the presence or absence of ipe extract. The ipe extract doses used are indicated in the appropriate figures and their legends.

\section{Determining NO production and lactate dehydrogenase (LDH)}

Culture medium was used for nitrite (stable metabolite of NO) for NO production measurements using the Griess method [18] and LDH activity for cellular viability using a commercial kit (Wako Pure Chemicals).

\section{Western blot analysis}

Total cell lysates were obtained from cultured cells [19], mixed with sodium dodecyl sulfatepolyacrylamide gel electrophoresis (SDS-PAGE) sample buffer (final concentrations: $125 \mathrm{mM}$ Tris-HCl pH 6.8, 5\% glycerol, 2\% SDS and 1\% 2-mercaptoethanol), subjected to SDS-PAGE and transferred onto polyvinylidene difluoride membranes (Bio-Rad Laboratories, Hercules, CA, USA). Immunostaining was performed using primary antibodies against mouse iNOS (Affinity BioReagents, Golden, CO, USA), human I $\mathrm{B} \alpha$, mouse IL-1RI (Santa Cruz Biotechnology, Santa Cruz, CA, USA) and rat b-tubulin (internal control; Clone TUB2.1; Sigma Chemical Co.), 
followed by visualization with an ECL blotting detection reagent (GE Healthcare Biosciences Corp., Piscataway, NJ, USA).

For Akt, total cell lysates prepared from $100-\mathrm{mm}$ dishes $\left(5 \times 10^{6}\right.$ cells/dish) were pre-cleared with Protein A (Sigma Chemical Co.) and then mixed with a mouse monoclonal antibody against human Akt1 (Akt5G3; Cell Signaling) and Protein G-Sepharose (Pharmacia LKB Biotech, Uppsala, Sweden). After incubation overnight at $4^{\circ} \mathrm{C}$, immunocomplexes were centrifuged (16,000 $\mathrm{g}$ for $5 \mathrm{~min}$ ). The beads were washed with solubilizing buffer, dissolved in SDS-PAGE sample buffer and analyzed using western blotting (SDS-PAGE in a gradient 6-9\% gel, Multigel II mini (Cosmo Bio Co., Ltd., Tokyo, Japan)) using rabbit polyclonal antibodies against human Akt and phospho- (Ser473) Akt (Cell Signaling) as primary antibodies. In the case of p65, nuclear extracts were immunoprecipitated with an anti-p65 antibody (H286; Santa Cruz Biotechnology). The bands were analyzed using western blotting (SDS-PAGE in a gradient 6\%-9\% gel, Multigel II mini (Cosmo Bio Co., Ltd.)) using an antibody against human NF-kB p65 (BD Transduction Laboratories, Lexington, KY, USA).

\section{Northern blot analysis and reverse transcriptase-polymerase chain reaction (RT-PCR)}

Total RNA was extracted from cultured hepatocytes using a guanidinium-phenol-chloroform method [20] with Trizol reagent (Invitrogen, Carlsbad, CA, USA) according to the manufacturer's instructions. Next, $10 \mu \mathrm{g}$ of total RNA was fractionated by $1 \%$ agarose-formaldehyde gel electrophoresis, transferred to nylon membranes (Nytran; Schleicher and Schuell, Dassel, Germany), immobilized by baking at $80^{\circ} \mathrm{C}$ for $1 \mathrm{~h}$ and hybridized with DNA probes. A cDNA probe for rat iNOS (830 bp) was described previously [21]. cDNAs encoding rat I $\mathrm{B} \alpha$, p65, IL1RI [22] and mouse glyceraldehyde-3-phosphate dehydrogenase (GAPDH) [23] were prepared using RT-PCR [24]. The cDNA was radiolabeled with $\left[\alpha-{ }^{32} \mathrm{P}\right] \mathrm{dCTP}$ usig the random priming method.

For strand-specific RT-PCR analysis, cDNA was synthesized from total RNA with strandspecific primers and step-down PCR was performed as previously described [24,25]. For iNOS and elongation factor (EF)-1 $\alpha$ (internal control) mRNAs, an oligo(dT) primer was used for RT and primer sets 5'-CCAACCTGCAGGTCTTCGATG-3' and

5'-GTCGATGCACAACTGGGTGAAC-3' (257-bp product) and

5'-TCTGGTTGGAATGGTGACAACATGC-3' and

5'-CCAGGAAGAGCTTCACTCAAAGCTT-3' (307-bp product) were used for PCR, respectively. For the iNOS antisense-transcript, sense primer

5'-TGCCCCTCCCCCACATTCTCT-3' was used for RT and the primer set

5'-ACCAGGAGGCGCCATCCCGCTGC-3' and

5'-CTTGATCAAACACTCATTTTATTAAA-3' (186-bp product) were used for PCR. The antisense-transcript levels were measured in triplicate by real-time PCR using an iCycler System (Bio-Rad Laboratories). SYBR Green I (Roche Diagnostics) was included in the reaction mixture, and the following touchdown protocol was applied: 1 cycle of $94^{\circ} \mathrm{C}$ for $1 \mathrm{~min}$; and 50 cycles of $94^{\circ} \mathrm{C}$ for $30 \mathrm{~s},(72-0.3 \times n)^{\circ} \mathrm{C}$ for $1 \mathrm{~min}$ where $n$ is number of cycles, and $72^{\circ} \mathrm{C}$ for $30 \mathrm{~s}$. Rat cDNAs for the iNOS mRNA and antisense-transcript were deposited in DDBJ/EMBL/GenBank under Accession Nos. AB250951 and AB250952, respectively. 


\section{Electrophoretic mobility shift assay (EMSA)}

Nuclear extracts were prepared according to Schreiber et al. [26] with minor modifications [27]. Binding reactions were performed by incubating nuclear extract aliquots ( $4 \mu \mathrm{g}$ of protein) in reaction buffer (20 mM Hepes $\mathrm{pH} 7.9,1 \mathrm{mM}$ EDTA, $60 \mathrm{mM} \mathrm{KCl}, 10 \%$ glycerol, $1 \mathrm{mg}$ of poly (dI$\mathrm{dC})$ ) with the probe (approximately $40,000 \mathrm{cpm}$ ) for $20 \mathrm{~min}$ at room temperature. The products were electrophoresed at $100 \mathrm{~V}$ in a $4.8 \%$ polyacrylamide gel in high ionic strength buffer $(50 \mathrm{mM}$ Tris-HCl, $380 \mathrm{mM}$ glycine, $2 \mathrm{mM}$ EDTA, $\mathrm{pH}$ 8.5) and the dried gels were analyzed using autoradiography. An NF- $\kappa \mathrm{B}$ consensus oligonucleotide

(5'-AGTTGAGGGGA-CTTTCCCAGGC-3') from mouse immunoglobulin $\mathrm{k}$ light chain was purchased from Promega (Madison, WI, USA) and labeled with $\left[\gamma_{-}{ }^{32} \mathrm{P}\right] \mathrm{ATP}$ and T4 polynucleotide kinase. The protein concentration was measured using the Bradford method [28] with a dye binding assay kit (Bio-Rad Laboratories).

\section{Construction of luciferase reporter plasmids and expression plasmids}

The 1.2-kb 5'-flanking region including the TATA box of the rat iNOS gene was inserted into the pGL3-Basic vector (Promega) to create pRiNOS-Luc-SVpA [27]. A rat cDNA for the 3'-UTR of the iNOS mRNA was amplified with the primers

5'-tgctctaGACAGTGAGGGGTTTGGAGAGA-3' and

5'-gcggatcctttaTTCTTGATCAAACACTCATTTT-3' and the resultant cDNA was digested with BamH I and Xba I. This cDNA for the iNOS 3'-UTR (submitted to DDBJ/EMBL/GenBank under Accession No. AB250951) was used to replace the SV40 polyadenylation signal (SVpA) of pRiNOS-Luc to create pRiNOS-Luc-3'UTR.

\section{Transfection and luciferase assay}

Transfection of cultured hepatocytes was performed as described previously [29,30]. Briefly, hepatocytes were cultured at $4 \times 10^{5}$ cells/dish $(35 \times 10 \mathrm{~mm})$ in WE supplemented with serum, dexamethasone and insulin for $7 \mathrm{~h}$, before being subjected to magnet-assisted transfection (MATra). Reporter plasmids pRiNOS-Luc-SVpA or pRiNOS-Luc-3'UTR $(1 \mu \mathrm{g})$ and the CMV promoterdriven $\beta$-galactosidase plasmid pCMV-LacZ (1 ng) as an internal control were mixed with MATraA reagent $(1 \mu \mathrm{l}$; IBA GmbH, Göttingen, Germany). After incubation for $15 \mathrm{~min}$ on a magnetic plate at room temperature, the medium was replaced with fresh WE containing serum. The cells were cultured overnight, and then treated with IL-1 $\beta$ in the presence or absence of dexamethasone. The cell extracts' luciferase and $\beta$-galactosidase activities were measured using PicaGene (Wako Pure Chemicals) and Beta-Glo (Promega) kits, respectively.

\section{Statistical analysis}

The results shown in the figures are representative of 3-4 independent experiments yielding similar findings. Differences were analyzed using the Bonferroni-Dunn test; values of $P<0.05$ were considered to indicate statistical significance.

\section{RESULTS}

\section{Ipe inhibits $\mathrm{NO}$ production and iNOS induction in hepatocytes}

The proinflammatory cytokine IL-1 $\beta$ stimulates iNOS induction, which was followed by NO production of in primary cultured rat hepatocytes [31]. The simultaneous addition of ipe and IL$1 \beta$ reduced the levels of nitrite (a stable metabolite of NO) time- and dose-dependently in the 
culture medium (Fig. 1A and 1B, upper). Ipe showed more than $90 \%$ inhibition at $2 \mathrm{mg} / \mathrm{ml}$. Ipe had no cellular cytotoxicity within the indicated concentrations, as evaluated by the release of LDH into the culture medium (Fig. 2) and Trypan blue exclusion by hepatocytes (data not shown).

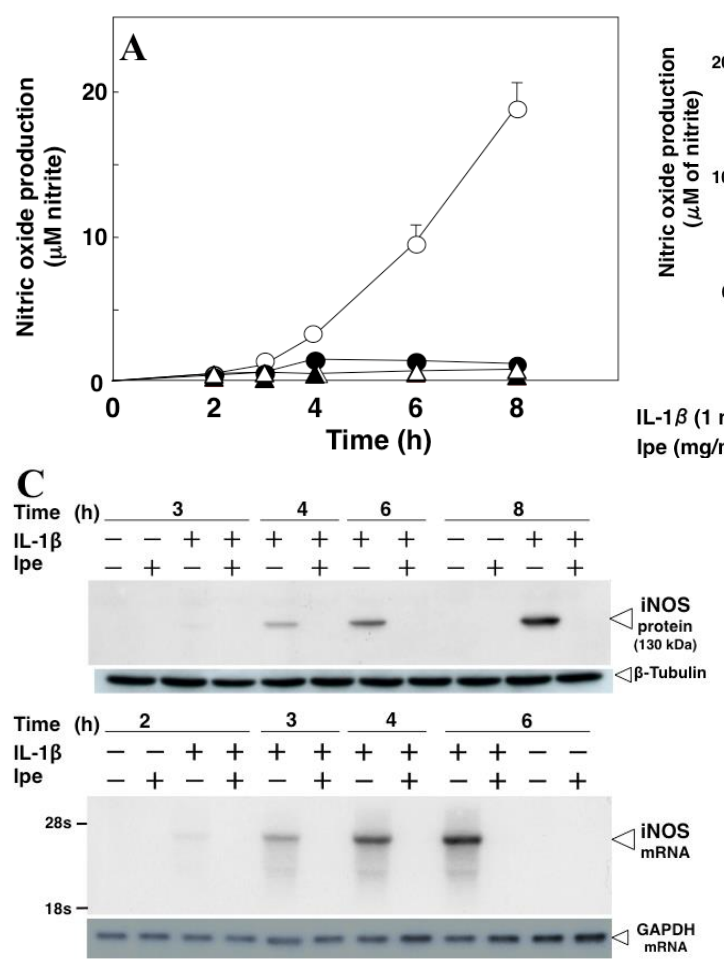

Figure 1. Effects of ipe extract on the induction of NO production and iNOS in hepatocytes. Cultured hepatocytes were treated with IL-1 $\beta(1 \mathrm{nM})$ in the presence or absence of ipe extract (ipe; $0.5-2 \mathrm{mg} / \mathrm{ml})$. (A) Effects of ipe extract $(2 \mathrm{mg} / \mathrm{ml})$ for the indicated times on NO production (IL-1 $\beta$, open circles; IL-1 $\beta+$ ipe, closed circles; ipe, closed triangles; controls (without IL-1 $\beta$ and ipe), open triangles). (B) Effects of various doses of ipe extract $(0.5-2 \mathrm{mg} / \mathrm{ml})$ over $8 \mathrm{~h}$ on NO production (top) and iNOS protein (middle). (C) Effects of ipe extract ( $2 \mathrm{mg} / \mathrm{ml}$ ) for the indicated times on the expression of iNOS protein and mRNA. The nitrite levels were measured in culture medium (data are means \pm SD with $n=3$ dishes/point; ${ }^{*} \mathrm{P}<0.05$ vs. IL- $1 \beta$ alone). In the western blotting panel, cell lysates (20 $\mu \mathrm{g}$ of protein) were subjected to SDS-PAGE in a $7.5 \% \mathrm{gel}$ and immunoblotted with an anti-iNOS or anti$\beta$-tubulin antibody. Total RNA (10 $\mu \mathrm{g})$ was analyzed using northern blotting and the filters were probed with labeled inserts for iNOS or GAPDH cDNA.

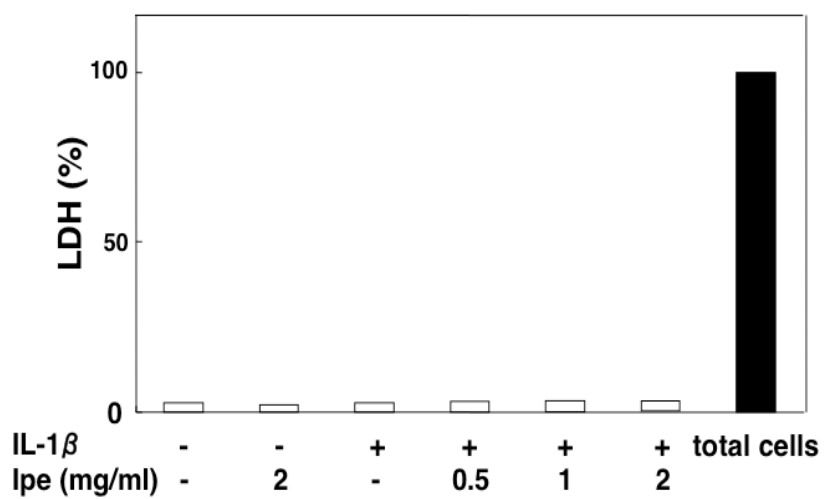

Figure 2. Effects of ipe extract on cellular cytotoxicity. Cultured hepatocytes were treated with IL-1 $\beta$ (1 $\mathrm{nM}$ ) in the presence or absence of ipe extract (ipe; $0.5-2 \mathrm{mg} / \mathrm{ml}$ ) for $8 \mathrm{~h}$. Lactate dehydrogenase (LDH) activities were measured in culture medium (data are means $\pm \mathrm{SD}$ with $\mathrm{n}=3$ dishes/point). 
Western blotting analysis revealed that ipe dose-dependently reduced iNOS protein expression, with the greatest effect at $2 \mathrm{mg} / \mathrm{mL}$ (Fig. 1B, middle). Western and northern blotting analyses demonstrated that ipe decreased the expression of iNOS protein and mRNA time-dependently (Fig. 1C). These results suggested that ipe inhibited iNOS gene expression induction at a transcriptional and/or post-transcriptional step.

\section{Ipe inhibits $N F-\kappa B$ activation and IL-1RI upregulation}

There are two essential signaling pathways for iNOS induction, I $\kappa \mathrm{B}$ kinase and phosphatidylinositol 3-kinase (PI3K)/Akt pathways [32]. In the former pathway, IL-1 $\beta$ stimulates I $\kappa$ B protein degradation after the phosphorylation by $\mathrm{I} \kappa \mathrm{B}$ kinase, which is followed by NF- $\kappa \mathrm{B}$ activation (that is, translocation from the cytoplasm to the nucleus and DNA binding). Ipe had no effect on I $\kappa \mathrm{B} \alpha$ degradation and recovery after IL-1 $\beta$ stimulation (Fig. 3, upper), whereas it tended to increase I $\kappa \mathrm{B} \alpha \mathrm{mRNA}$ expression levels at 1-3 h (Fig. 3, lower).

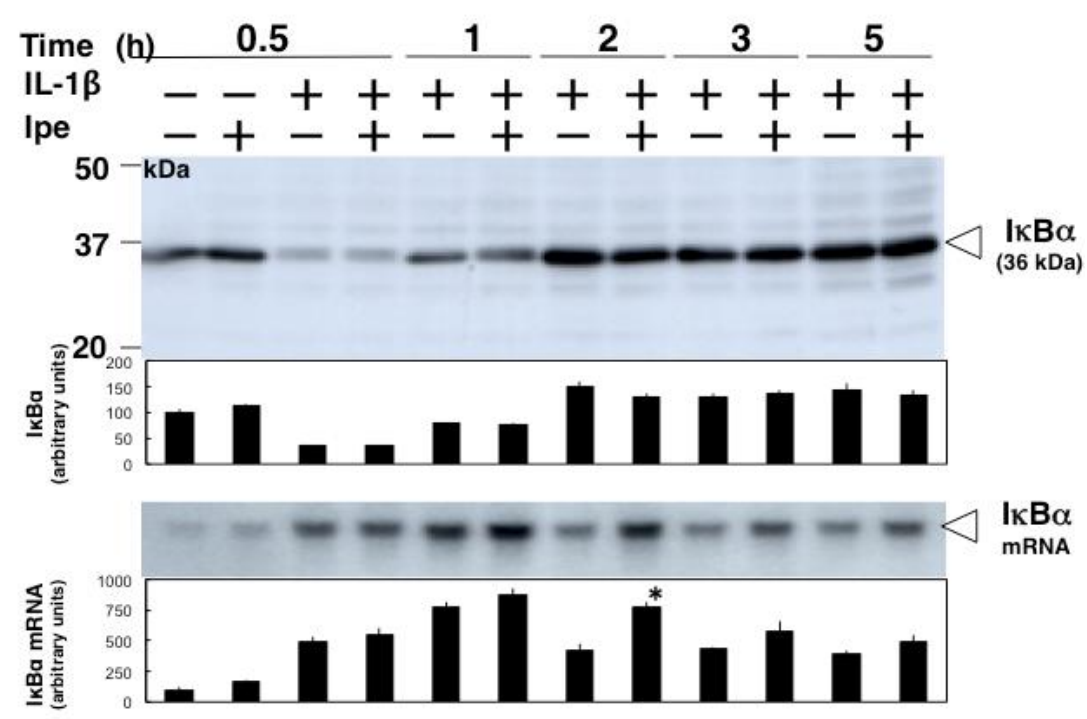

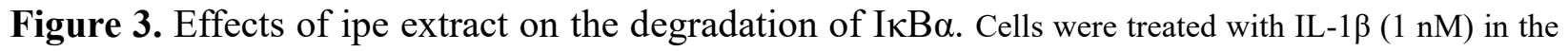
presence or absence of ipe extract $(2 \mathrm{mg} / \mathrm{ml})$ for the indicated times. Cell lysates ( $20 \mu \mathrm{g}$ of protein) were subjected to SDS-PAGE in a $12.5 \%$ gel, followed by immunoblotting with an anti-I $\kappa B \alpha$ antibody. Total RNA $(10 \mu \mathrm{g})$ was analyzed by northern blotting and the filters were probed with labeled inserts for I $\mathrm{B} \alpha \mathrm{cDNA}$. Representative results of three independent experiments are shown. The bands corresponding to I $\kappa \mathrm{B}$ protein or mRNA were quantitated using densitometry (mean $\pm \mathrm{SD} ; \mathrm{n}=3$ experiments). ${ }^{*} \mathrm{P}<0.05$ versus IL-1 $\beta$ alone

Conversely, the electrophoretic mobility shift assay with nuclear extracts revealed that ipe inhibited NF- $\mathrm{KB}$ activation at $4 \mathrm{~h}$ and thereafter (Fig. 4A, left), although ipe had no effect at 1-3 $\mathrm{h}$. In support of this observation, immunoprecipitation and western blotting experiments with nuclear

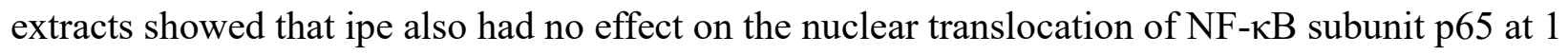
$\mathrm{h}$, but decreased nuclear p65 levels at $5 \mathrm{~h}$ (Fig. 4B, upper). Ipe also reduced p65 mRNA expression levels at 2-3 h (Fig. 4B, lower). Supershift experiments revealed that ipe did not influence the

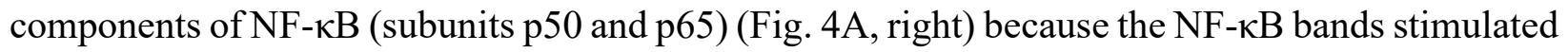
by IL-1 $\beta$ disappeared similarly in the presence of antibodies against $\mathrm{p} 50$ and $\mathrm{p} 65$, irrespective of the presence of ipe. 


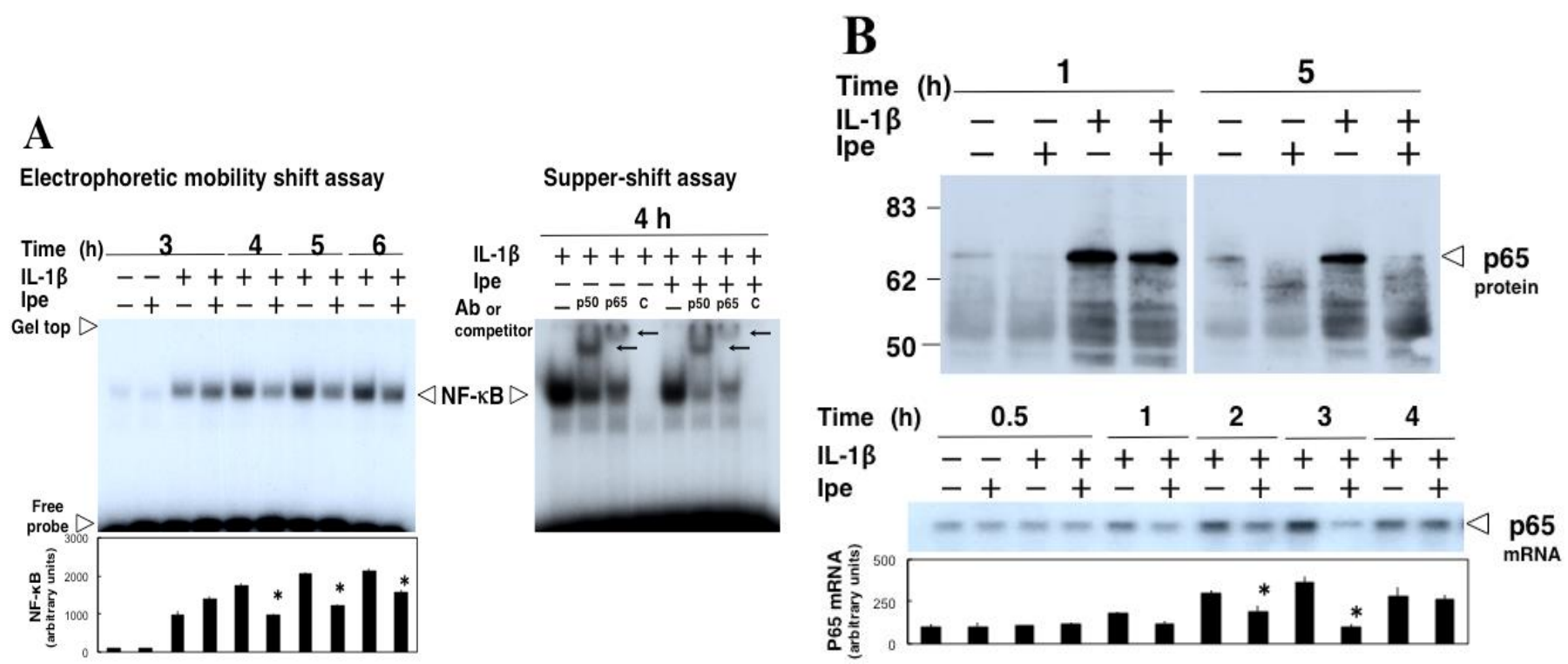

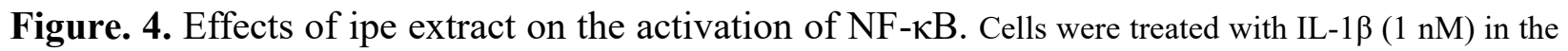
presence or absence of ipe extract (ipe; $2 \mathrm{mg} / \mathrm{ml}$ ) for the indicated times. (A) Activation of NF- $\mathrm{kB}$; nuclear extracts (4 $\mu \mathrm{g}$ of protein) were analyzed by EMSAs (left). Supershift assay (right); nuclear extracts were incubated with a labeled $\mathrm{NF}-\mathrm{kB}$ consensus oligonucleotide in the presence of an anti-p50 antibody, anti-p65 antibody or cold probe as a competitor (C, 250-fold excess). Closed arrows show supershifted bands. (B) Nuclear translocation of NF-kB subunit p65 and its mRNA expression; nuclear extracts were immunoprecipitated and the immunoprecipitates were analyzed by western blotting with an anti-p65 antibody (upper). Total RNA $(10 \mu \mathrm{g})$ was analyzed by northern blotting and the filters were probed with labeled inserts for p 65 cDNA (lower). The bands corresponding to NF- $\mathrm{kB}$ or p $65 \mathrm{mRNA}$ were quantitated using densitometry (mean $\pm \mathrm{SD} ; \mathrm{n}=3$ experiments). $* \mathrm{P}<0.05$ versus IL- $1 \beta$ alone

In the latter pathway, IL-1 $\beta$ stimulates IL-1RI upregulation through PI3K/Akt activation [32]. Immunoprecipitation-western blotting analysis revealed that ipe inhibited Akt (a downstream kinase of PI3K) phosphorylation (activation) at $0.5 \mathrm{~h}$ (Fig. 5A). Northern and western blotting analyses revealed that ipe reduced both IL-1RI mRNA and protein expression levels (Fig. 5B and $5 C)$.
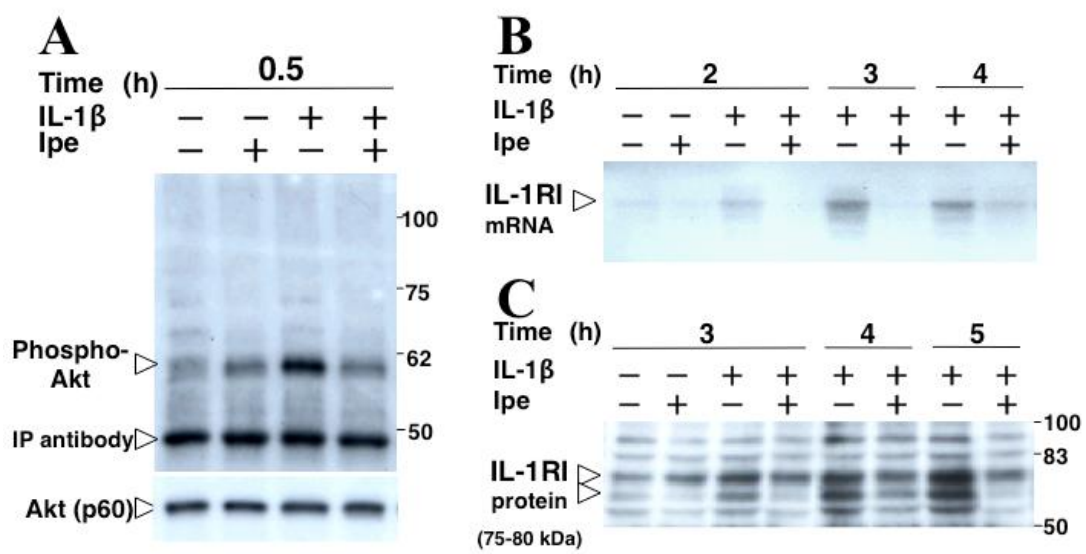

Figure 5. Effects of ipe extract on IL-1RI upregulation. Cells were treated with IL-1 $(1 \mathrm{nM})$ in the presence or absence of ipe extract (ipe; $2 \mathrm{mg} / \mathrm{ml}$ ) for the indicated times. (A) Phosphorylation of Akt. Total cell lysates were immunoprecipitated with an anti-Akt antibody, followed by immunoblotting with an anti-phospho-Akt or antiAkt antibody. (B) Total RNA $(10 \mu \mathrm{g})$ was analyzed by northern blotting and the filters were probed with labeled inserts for IL-1RI cDNA. (C) Cell lysates (50 $\mu$ g of protein) were subjected to SDS-PAGE in a 7.5\% gel and immunoblotted with an anti-IL-1RI antibody. 


\section{Ipe decreases iNOS mRNA synthesis and stabilization}

We examined the mechanisms involved in the inhibition of iNOS induction. iNOS mRNA expression is regulated by iNOS promoter transactivation with transcription factors such as NF$\kappa \mathrm{B}$ and by post-transcriptional modifications such as mRNA stabilization [33]. Therefore, we conducted transfection experiments with constructs containing firefly luciferase controlled by the iNOS promoter (pRiNOS-Luc-SVpA and pRiNOS-Luc- 3'UTR), which detect iNOS promoter transactivation (mRNA synthesis) and mRNA stabilization, respectively [34]. IL-1 $\beta$ increased these constructs' luciferase activities; these effects were significantly inhibited by ipe (Fig. 6).

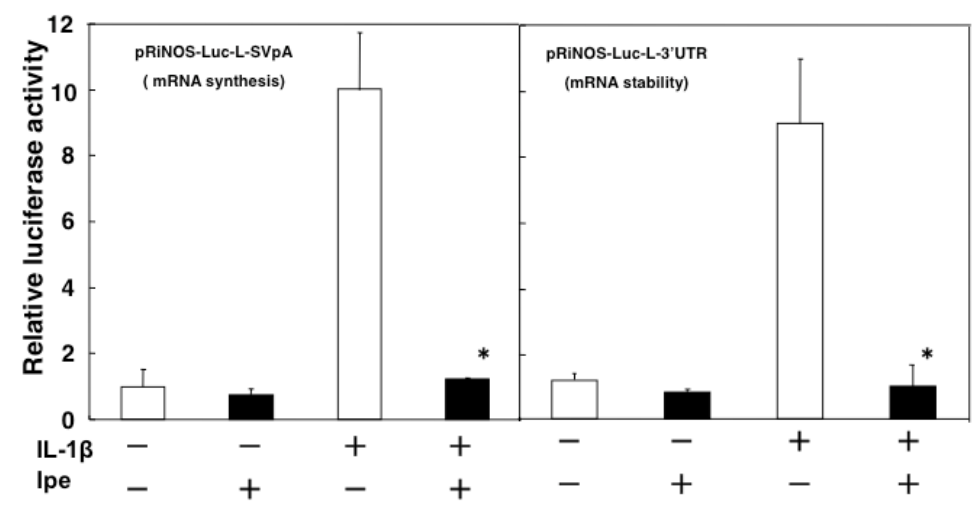

Figure 6. Effects of ipe extract on the transactivation of the iNOS promoter. The constructs consist of the rat iNOS promoter $(1.2 \mathrm{~kb}$ ), luciferase gene and SV40 poly(A) region (pRiNOS-Luc-SVpA) or iNOS 3'-UTR (pRiNOS-Luc-3'UTR). The iNOS 3'-UTR contains AU-rich elements (AUUU(U)A x 6), which contribute to mRNA stabilization. Each construct was introduced into hepatocytes and the cells were treated with IL-1 $\beta(1 \mathrm{nM})$ in the presence or absence of ipe extract (ipe; $2 \mathrm{mg} / \mathrm{ml}$ ) for $8 \mathrm{~h}$ for pRiNOS-Luc-SVpA (left) and $4 \mathrm{~h}$ for pRiNOS-Luc3'UTR (right). The luciferase activities were normalized by the $\beta$-galactosidase activity. The fold activation was calculated by dividing the luciferase activity by that of the control (without IL- $1 \beta$ and ipe). Data are means \pm SD ( $\mathrm{n}=$ 4 dishes). $* \mathrm{P}<0.05$ vs. IL- $1 \beta$ alone.

We have recently reported that the natural antisense-transcript of the iNOS gene upregulates iNOS mRNA stability in IL-1 $\beta$-stimulated hepatocytes [35]. RT-PCR and quantitative real-time PCR experiments revealed that IL-1 $\beta$ time-dependently increased the iNOS gene antisensetranscript expression with increased iNOS mRNA levels and that ipe decreased both antisensetranscript and iNOS mRNA levels (Fig. 7).

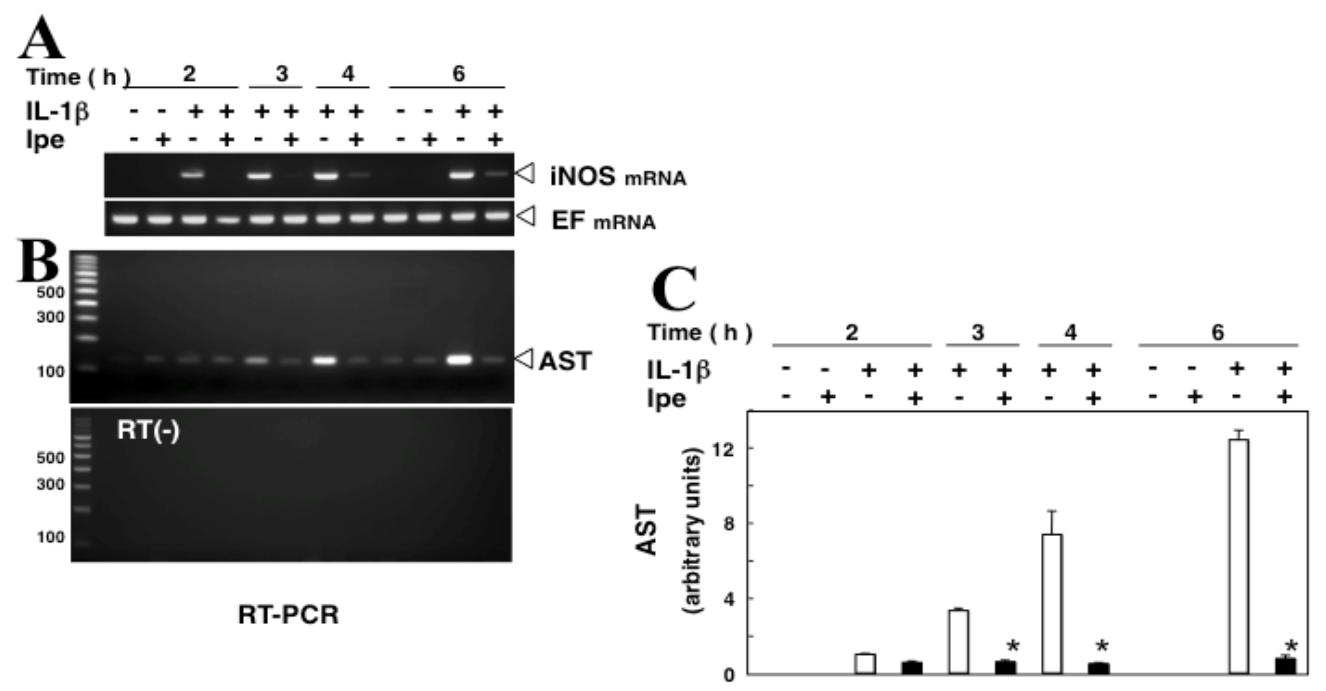

Figure 7. Effects of ipe extract on the expression of the iNOS gene antisense-transcript in hepatocytes. Cells were treated with IL-1 $\beta(1 \mathrm{nM})$ in the presence or absence of ipe extract (ipe; $2 \mathrm{mg} / \mathrm{ml}$ ) for the 
indicated times. Total RNA was analyzed by strand-specific RT-PCR to detect (A) iNOS with EF-1 $\alpha$ (EF) as an internal control and (B) the iNOS gene antisense-transcript (AST). (C) Quantitative RT-PCR was conducted for the iNOS gene AST and the copy number of the iNOS gene AST was normalized by that of a negative PCR control using total RNA without $\mathrm{RT}(\mathrm{RT}(-))$. Data are means $\pm \mathrm{SD}\left(\mathrm{n}=3\right.$ experiments). ${ }^{*} \mathrm{P}<0.05$ vs. IL- $1 \beta$ alone.

\section{DISCUSSION}

In this study, we found that ipe inhibited iNOS induction in IL-1 $\beta$ stimulated hepatocytes, which indicates that ipe may have an anti-inflammatory effect in the liver. Our simple in vitro experiment with cultured hepatocytes may be adequate for screening of liver-protective drugs, because it is rapid and inexpensive compared with in vivo animal models of liver injury. However, there are various factors involved in liver injury in addition to iNOS and proinflammatory cytokines. Thus, a liver-protective effect in drugs deduced from this model need to be examined and supported in in vivo animal models.

iNOS gene expression induction is regulated by iNOS promoter transactivation and by posttranscriptional modifications [36]. NF- $\mathrm{kB}$ plays a key role in inflammation by regulating genes encoding iNOS and proinflammatory cytokines such as TNF- $\alpha$ [37]. NF- $\kappa$ B typically exists in the

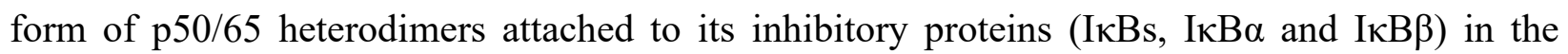
cytoplasm of cells. NF- $\kappa$ B activation involves i) the proteolytic degradation of I $\kappa$ Bs in proteosome after phosphorylation by $\mathrm{I} \kappa \mathrm{B}$ kinase, ii) the translocation of NF- $\kappa \mathrm{B}$ to the nucleus and iii) its binding to the promoter $\kappa \mathrm{B}$ site [38]. Ipe inhibited NF- $\kappa \mathrm{B}$ activation (Fig. 4A) and p65 translocation to the nucleus (Fig. 4B), although it had no effect on IкB adegradation (Fig. 3A). In concert with NF- $\kappa \mathrm{B}$ activation, IL-1RI upregulation through PI3K/Akt activation is also essential for iNOS induction [32]. Ipe inhibited Akt activation (phosphorylation) (Fig. 5A), up-stream kinase in this signal, which resulted in decreased IL-1RI mRNA and protein expression (Fig. 5B and $5 \mathrm{C}$ ).

Furthermore, in experiments with iNOS promoter constructs, ipe inhibited iNOS induction at both of its mRNA synthesis and stabilization steps (Fig. 6). Regarding iNOS mRNA stabilization, the 3 '-UTR of the iNOS mRNA in rats has six adenine/uracil (AU)-rich elements (ARE) that are associated with ARE-binding proteins such as $\mathrm{HuR}$ and heterogeneous nuclear ribonucleoproteins L/I (PTB), which serve to stabilize the mRNA [39]. Recently, we reported that antisense (as)RNAs are often transcribed from many inducible genes, such as iNOS and TNF- $\alpha$ [40]. The iNOS asRNA interacts with and stabilizes iNOS mRNA $[35,41]$. We reported that drugs such as edaravone (free radical scavenger) [42], FR183998 $\left(\mathrm{Na}^{+} / \mathrm{H}^{+}\right.$exchanger inhibitor) [9,11], insulin growth factor I [10], sivelestat [43], kampo inchinkoto (TJ-135) [44], kampo saireito (TJ-114) [45] and kampo hochuekito (TJ-41) [46] inhibited iNOS induction partly by suppressing iNOS asRNA production in animal models and/or primary cultured hepatocytes. In this study, ipe also decreased the iNOS asRNA expression (Fig. 7).

These results demonstrate that ipe inhibits two essential signaling pathways, NF- $\kappa \mathrm{B}$ activation and IL-1RI upregulation in the induction of iNOS. Ipe probably reduced iNOS mRNA expression by inhibiting its mRNA synthesis and stabilization, which decreased iNOS protein and NO production. In the clinical study, we would like to examine the Ipe treatment in patients with sepsis in future. Lapachol, one of Ipe ingredients, will be examined to our in vitro (IL-1 $\beta$ treated culture hepatocytes) and in vivo (animal models of liver injury) studies. 


\section{CONCLUSION}

Ipe can prevent IL-1 $\beta$-stimulated liver injury in cultured hepatocytes by inhibiting the induction of inflammatory mediator iNOS gene expression, in part by inhibiting NF-kB activation. Ipe may have therapeutic potential for liver injury.

Abbreviations: iNOS, inducible nitric oxide synthase; NO, nitric oxide; IL-1 $\beta$, interleukin-1 $\beta$; NF- $\kappa \mathrm{B}$, nuclear factor-kappa B; IL-1RI, the type I interleukin-1 receptor; TNF- $\alpha$, tumor necrosis factor-alpha; CINC-1, cytokine-induced neutrophil chemoattractant-1; WE, Williams' Medium E

Competing Interest: The authors declare that they have no conflicts of interest.

Authors' Contributions: T. Ozaki participated in data collection, statistical analysis and manuscript drafting. Y. Kawaguchi and M. Nishizawa assisted in the design of the study and in supervision. K. Matsui, M. Kotsuka and H. Iida participated in data collection. T. Okumura gave significant advice regarding protocol development and participated in manuscript drafting. M. Kaibori and M. Sekimoto assisted in the design of the study and in financial support.

Acknowledgments and Funding: This work was supported in part by a Grant-in-Aid for Scientific Research from the Ministry of Education, Culture, Sports, Science and Technology of Japan and by grants from the Science Research Promotion Fund of the Japan Private School Promotion Foundation.

\section{REFERENCES}

1. Pereira IT, Burci LM, da Silva LM, Baggio CH, Heller M, Micke GA, Pizzolatti MG, et al.: Antiulcer effect of bark extract of Tabebuia avellanedae: activation of cell proliferation in gastric mucosa during the healing process. Phytother Res. 2013, 27:1067-1073.

2. Park BS, Lee HK, Lee SE, Piao XL, Takeoka GR, Wong RY, Ahn YJ, et al.: Antibacterial activity of Tabebuia impetiginosa Martius ex DC (Taheebo) against Helicobacter pylori. J Ethnopharmacol. 2006, 105:255-262.

3. Park BS, Lee KG, Shibamoto T, Lee SE, Takeoka GR: Antioxidant activity and characterization of volatile constituents of Taheebo (Tabebuia impetiginosa Martius ex DC). J Agric Food Chem. 2003, 51:295-300.

4. Choi BT, Cheong J, Choi YH: beta-Lapachone-induced apoptosis is associated with activation of caspase-3 and inactivation of NF-kappaB in human colon cancer HCT-116 cells. Anticancer Drugs 2003, 14:845-850.

5. Pardee AB, Li YZ, Li CJ: Cancer therapy with beta-lapachone. Curr Cancer Drug Targets 2002, 2:227-242.

6. Colasanti M, Suzuki H. The dual personality of NO. Trends Pharmacol Sci 2000, 21:249-52.

7. Tsuchiya H, Kaibori M, Yanagida H, Yokoigawa N, Kwon AH, Okumura T, Kamiyama Y: Pirfenidone prevents endotoxin-induced liver injury after partial hepatectomy in rats. J Hepatol 2004, 40: 94-101. 
8. Tsuji K, Kwon AH, Yoshida H, Qiu Z, Kaibori M, Okumura T, Kamiyama Y: Free radical scavenger (edaravone) prevents endotoxin-induced liver injury after partial hepatectomy in rats. J Hepatol 2005, 42:94-101.

9. Tanaka H, Uchida Y, Kaibori M, Hijikawa T, Ishizaki M, Yamada M, Matsui K, et al.: $\mathrm{Na}+\mathrm{H}+$ exchanger inhibitor, FR183998, has protective effect in lethal acute liver failure and prevents iNOS induction in rats. J Hepatol 2008, 48:289-99.

10. Hijikawa T, Kaibori M, Uchida Y, Yamada M, Matsui K, Ozaki T, Kamiyama Y, et al.: Insulin-like growth factor 1 prevents liver injury through the inhibition of TNF-a and iNOS induction in D-galactosamine and lipopolysaccharide-treated rats. Shock 2008, 29:740-7.

11. Ishizaki M, Kaibori M, Uchida Y, Hijikawa T, Tanaka H, Ozaki T, Tokuhara K, et al.: Protective effect of FR183998, a Na+/H+ exchanger inhibitor, and its inhibition of iNOS induction in hepatic ischemia-reperfusion injury in rats. Shock 2008, 30: 311-17.

12. Nakanishi H, Kaibori M, Teshima S, Yoshida H, Kwon AH, Kamiyama Y, Nishizawa $\mathrm{M}$, et al.: Pirfenidone inhibits the induction of iNOS stimulated by interleukin-1b at a step of NF-kB DNA binding in hepatocytes. J Hepatol 2004, 41:730-6.

13. Yoshida H, Kwon AH, Kaibori M, Tsuji K, Habara K, Yamada M, Kamiyama Y, et al.: Edaravone prevents iNOS expression by inhibiting its promoter transactivation and mRNA stability in cytokine-stimulated hepatocytes. Nitric Oxide 2008, 18:105-12.

14. Awale S, Kawakami T, Tezuka Y, Ueda JY, Tanaka K, Kadota S: Nitric oxide (NO) production inhibitory constituents of Tabebuia avellanedae from Brazil. Chem Pharm Bull (Tokyo) 2005, 53:710-713.

15. Kanemaki T, Kitade H, Hiramatsu Y, Kamiyama Y, Okumura T: Stimulation of glycogen degradation by prostaglandin E2 in primary cultured rat hepatocytes. Prostaglandins 1993, 45:459-474.

16. Seglen PO: Preparation of isolated rat liver cells. Methods in Cell Biology 1976, 13:2983.

17. Horiuti Y, Ogishima M, Yano K, Shibuya Y: Quantification of cell nuclei isolated from hepatocytes by cell lysis with nonionic detergent in citric acid. Cell Struct Funct 1991, 16: 203-207.

18. Green LC, Wagner DA, Glogowski J, Skipper PL, Wishnok JS, Tannenbaum SR: Analysis of nitrate, nitrite and [15N] nitrate in biological fluids. Anal Biochem 1982, 126:131-138.

19. Nakanishi H, Kaibori M, Teshima S, Yoshida H, Kwon AH, Kamiyama Y, Nishizawa M, et al.: Pirfenidone inhibits the induction of iNOS stimulated by interleukin-1 $\beta$ at a step of NF-kB DNA binding in hepatocytes. J Hepatol 2004, 41:730-736.

20. Chomczynski P, Sacchi N: Single-step method of RNA isolation by acid guanidium thiocyanate-phenol-chloroform extraction. Anal Biochem 1987, 162:156-159.

21. Nunokawa Y, Ishida N, Tanaka S: Cloning of inducible nitric oxide synthase in rat vascular smooth muscle cells. Biochem Biophys Res Commun 1993, 191:89-94.

22. Hart RP, Liu C, Shadiack AM, McCormack RJ, Jonakait GM: An mRNA homologous to interleukin-1 receptor type I is expressed in cultured rat sympathetic ganglia. J Neuroimmunol 1993, 44:49-56. 
23. Sabath DE, Broome HE, Prystowsky MB: Glyceraldehyde-3-phosphate dehydrogenase mRNA is a major interleukin 2-induced transcript in a cloned T-helper lymphocyte. Gene 1990, 91:185-191, 1990.

24. Nishizawa M, Nakajima T, Yasuda K, Kanzaki H, Sasaguri Y, Watanabe K, Ito S: Close kinship of human 20alpha-hydroxysteroid dehydrogenase gene with three aldoketo reductase genes. Genes Cells 200, 5:111-125.

25. Unezaki S, Nishizawa M, Okuda-Ashitaka E, Masu Y, Mukai M, Kobayashi S, Sawamoto K, et al.: Characterization of the isoforms of MOVO zinc finger protein, a mouse homologue of Drosophila Ovo, as transcription factors. Gene 2004, 336:47-58.

26. Schreiber E, Matthias P, Müller MM, Schaffner W: Rapid detection of octamer binding proteins with mini-extracts, prepared from a small number of cells. Nucleic Acids Res 1989, 17:6419.

27. Oda M, Sakitani K, Kaibori M, Inoue T, Kamiyama Y, Okumura T: Vicinal dithiolbinding agent, phenylarsine oxide, inhibits iNOS gene expression at a step of NF- $\kappa \mathrm{B}$ DNA binding in hepatocytes. J Biol Chem 2000, 275:4369-4373.

28. Bradford MM: A rapid and sensitive method for the quantitation of microgram quantities of protein utilizing the principle of protein-dye binding. Anal Biochem 1976, 72:248254.

29. Sakitani K, Kitade H, Inoue K, Kamiyama Y, Nishizawa M, Ito S, Okumura T: Antiinflammatory drug sodium salicylate inhibits nitric oxide formation induced by interleukin-1 $\beta$ at a translational step, but not a transcriptional step, in hepatocytes. Hepatology 1997, 25: 416-420.

30. Inoue $\mathrm{T}$, Kwon $\mathrm{AH}$, Oda $\mathrm{M}$, Kaibori M, Kamiyama Y, Nishizawa M, Ito S, et al.: Hypoxia and heat inhibit inducible nitric oxide synthase gene expression by different mechanisms in rat hepatocytes. Hepatology 2000, 32:1037-1044.

31. Kitade H, Sakitani K, Inoue K, Masu Y, Kawada N, Hiramatsu Y, Kamiyama Y, et al.: Interleukin-1b markedly stimulates nitric oxide formation in the absence of other cytokines or lipopolysaccharide in primary cultured rat hepatocytes, but not in Kupffer cells. Hepatology 1996, 23:797-802.

32. Teshima S, Nakanishi H, Nishizawa M, Kitagawa K, Kaibori M, Yamada M, Habara K, et al.: Up-regulation of IL-1 receptor through PI3K/Akt is essential for the induction of iNOS gene expression in hepatocytes. J Hepatol 2004, 40:616-23.

33. Kleinert H, Pautz A, Linker K, Schwarz PM: Regulation of the expression of inducible nitric oxide synthase. Eur J Pharmacol 2004, 500:255-66.

34. Yamada M, Nishizawa M, Nakatake R, Habara K, Yoshida H, Ozaki T, Matsui K, et al.: Characterization of alternatively spliced isoforms of the type I interleukin-1 receptor on iNOS induction in rat hepatocytes. Nitric Oxide Biol Chem 2007, 17:98-105.

35. Matsui K, Nishizawa M, Ozaki T, Kimura T, Hashimoto I, Yamada M, Kaibori M, et al.: Natural antisense transcript stabilizes inducible nitric oxide synthase mRNA in rat hepatocytes. Hepatology 2008, 47:686-697.

36. Kleinert H, Pautz A, Linker K, Schwarz PM: Regulation of the expression of inducible nitric oxide synthase. Eur J Pharmacol 2004, 500:255-66.

37. Lawrence T: The nuclear factor NF- $\kappa B$ pathway in inflammation, Cold Spring Harb Perspect Biol 2009, 1:a001651. 
38. Akira S, Kishimoto T.: NF-IL6 and NF-kB in cytokine gene regulation. Adv Immunol 1997, 65:1-46.

39. Pautz A, Linker K, Hubrich R, Korhonen R, Altenhofer S, Kleinhert H: The polypyrimidine tract-binding protein (PTB) is involved in the post-transcriptional regulation of human inducible nitric oxide synthase expression. J Biol Chem 2006, 281:32294-302.

40. Nishizawa M, Okumura T, Ikeya Y, Kimura T: Regulation of inducible gene expression by natural antisense transcripts. Front. Biosci. 2012, 17:938-958.

41. Yoshigai E, Hara T, Araki Y, Tanaka Y, Oishi M, Tokuhara K, Kaibori M, et al.: Natural antisense transcript-targeted regulation of inducible nitric oxide synthase mRNA levels. Nitric oxide 2013, 30:9-16.

42. Yoshida H, Kwon AH, Kaibori M, Tsuji K, Habara K, Yamada M, Kamiyama Y, et al.: Edaravone prevents iNOS expression by inhibiting its promoter transactivation and mRNA stability in cytokine-stimulated hepatocytes. Nitric Oxide 2008, 18:105-12.

43. Araki Y, Matsumiya M, Matsuura T, Kaibori M, Okumura T, Nishizawa M, Kwon AH: Sivelestat suppresses iNOS gene expression in proinflammatory cytokinestimulatied hepatocytes. Dig Dis Sci 2011, 56:1672-81.

44. Matsuura T, Kaibori M, Araki Y, Matsumiya M, Yamamoto Y, Ikeya Y, Nishizawa M, et al.: Japanese herbal medicine, inchinkoto, inhibits inducible nitric oxide synthase induction in interleukin-1 $\beta$-stimulated hepatocytes. Hepatol Res 2012, 42(1):76-90.

45. Miki H, Tokuhara K, Oishi M, Nakatake R, Tanaka Y, Kaibori M, Nishizawa M, et al.: Japanese Kampo Saireito Has a Liver-Protective Effect Through the Inhibition of Inducible Nitric Oxide Synthase Induction in Primary Cultured Rat Hepatocytes. JPEN J Parenter Enteral Nutr 2016, 40(7):1033-1041.

46. Matsumiya M, Kaibori M, Araki Y, Matsuura T, Oishi M, Tanaka Y, Nishizawa M, et al.: Japanese herbal medicine hochuekkito inhibits the expression of proinflammatory biomarker, inducible nitric oxide synthase, in hepatocytes. Medchem 2012, 2(2): 112. 